\title{
Regulation of PPAR $\gamma$ Gene Expression by Nutrition and Obesity in Rodents
}

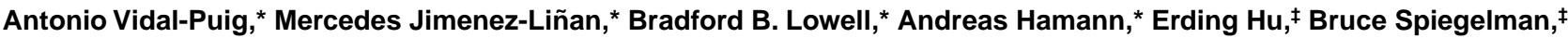 \\ Jeffrey S. Flier, ${ }^{\star}$ and David E. Moller*§ \\ *Department of Medicine, Beth Israel Hospital, ${ }^{\ddagger}$ Dana Farber Institute and Harvard Medical School, Boston, Massachusetts 02215; and \\ ${ }^{\S}$ Department of Molecular Endocrinology, Merck Research Laboratories, Rahway, New Jersey 07065
}

\begin{abstract}
The orphan nuclear receptor, peroxisome proliferator-activated receptor (PPAR) $\gamma$, is implicated in mediating expression of fat-specific genes and in activating the program of adipocyte differentiation. The potential for regulation of PPAR $\gamma$ gene expression in vivo is unknown. We cloned a partial mouse PPAR $\gamma$ cDNA and developed an RNase protection assay that permits simultaneous quantitation of mRNAs for both $\gamma 1$ and $\gamma 2$ isoforms encoded by the PPAR $\gamma$ gene. Probes for detection of adipocyte P2, the obese gene product, leptin, and $18 \mathrm{~S}$ mRNAs were also employed. Both $\gamma 1$ and $\gamma 2 \mathrm{mRNAs}$ were abundantly expressed in adipose tissue. PPAR $\gamma 1$ expression was also detected at lower levels in liver, spleen, and heart; whereas, $\gamma 1$ and $\gamma 2$ mRNA were expressed at low levels in skeletal muscle. Adipose tissue levels of $\gamma 1$ and $\gamma 2$ were not altered in two murine models of obesity (gold thioglucose and ob/ob), but were modestly increased in mice with toxigene-induced brown fat ablation uncoupling protein diphtheria toxin A mice. Fasting (12-48 h) was associated with an $80 \%$ fall in PPAR $\gamma 2$ and a $50 \%$ fall in PPAR $\gamma 1 \mathrm{mRNA}$ levels in adipose tissue. Western blot analysis demonstrated a marked effect of fasting to reduce PPAR $\gamma$ protein levels in adipose tissue. Similar effects of fasting on PPAR $\gamma$ mRNAs were noted in all three models of obesity. Insulin-deficient (streptozotocin) diabetes suppressed adipose tissue $\gamma 1$ and $\gamma 2$ expression by $75 \%$ in normal mice with partial restoration during insulin treatment. Levels of adipose tissue PPAR $\gamma 2$ mRNA were increased by $\mathbf{5 0 \%}$ in normal mice exposed to a high fat diet. In obese uncoupling protein diphtheria toxin A mice, high fat feeding resulted in de novo induction of PPAR $\gamma 2$ expression in liver. We conclude (a) PPAR $\gamma 2$ mRNA expression is most abundant in adipocytes in normal mice, but lower level expression is seen in skeletal muscle; $(b)$ expression of adipose tissue $\gamma 1$ or $\gamma 2$ mRNAs is increased in only one of the three models of obesity; (c) PPAR $\gamma 1$ and $\gamma 2$ expression is downregulated by fasting and insulin-deficient diabetes; and $(d)$ exposure of mice to a high fat diet increases adipose
\end{abstract}

A. Hamann's present address is University of Hamburg, Hamburg Germany 20246.

Address correspondence to Jeffrey S. Flier, Endocrine Division, Beth Israel Hospital, 99 Brookline Avenue, Boston, MA 02215. Phone: 617-667-2151; FAX: 617-667-2927; or David E. Moller, Department of Molecular Endocrinology, Merck Research Laboratories, Rahway, NJ 07065. Phone: 908-594-1547; FAX: 908-594-5700.

Received for publication 1 December 1995 and accepted in revised form 20 March 1996.

J. Clin. Invest.

(C) The American Society for Clinical Investigation, Inc.

0021-9738/96/06/2553/09 \$2.00

Volume 97, Number 11, June 1996, 2553-2561 tissue expression of PPAR $\gamma$ (in normal mice) and induces PPAR $\gamma 2$ mRNA expression in liver (in obese mice). These findings demonstrate in vivo modulation of PPAR $\gamma$ mRNA levels over a fourfold range and provide an additional level of regulation for the control of adipocyte development and function. (J. Clin. Invest. 1996. 97:2553-2561.) Key words: peroxisome proliferator-activated receptor $\bullet$ obesity $\bullet$ nutrition $\bullet$ insulin $\cdot$ gene regulation

\section{Introduction}

Obesity, defined as a state of pathologically increased adipose cell mass (1), is a major health problem in wealthy societies and is associated with increased risk of developing diabetes, hypertension, and hyperlipidemia. Increased mortality (2) is not only associated with morbid obesity as recent reports have shown that modestly increased body weight is an important determinant of mortality among middle-aged women (3). Although the adipocyte has previously been viewed as a passive participant in the generation of obesity, this cell has recently been recognized as having a more active role in the regulation of energy homeostasis and body composition (1). Thus there is rapidly advancing knowledge about the mechanisms that direct adipocyte differentiation and adipocyte-specific gene expression. Studies of the proximal promoter region of the adipocyte P2 (aP2) ${ }^{1}$ gene (which encodes an intracellular lipid-binding protein specifically expressed in adipocytes), have identified binding sites for transcription factors AP-1 and CCAAT/enhancer binding protein (4-8). These factors, especially CCAAT/ enhancer binding protein, appear to be involved in terminal adipocyte differentiation, but may not have a specific role in the initiation of the adipocyte program or tissue specificity. Analysis of another region located $5.4 \mathrm{~kb}$ upstream from the aP2 transcriptional start site revealed a 500-bp sequence which was shown to mediate differentiation-dependent and tissuespecific aP2 expression (9-11). Included in this region are enhancers, adipocyte regulatory elements- 6 and -7 , that contain imperfect versions of a DR-1 consensus sequence that is known to bind to orphan nuclear receptors in the peroxisome proliferator-activated receptor (PPAR) family. Three PPAR genes, PPAR $\alpha$ (12), PPAR $\delta$ (NUC1) (13), and PPAR $\gamma(9,14)$, encode different members of this family of orphan receptors.

Recently, Tontonoz et al. (11) cloned a binding factor for adipocyte regulatory element- 6 and showed it to be an isoform of PPAR $\gamma(\operatorname{PPAR} \gamma 2)$. Forced expression of PPAR $\gamma 2$ or $\gamma 1$ in fibroblasts was sufficient to drive the determination of an adipocyte cellular lineage (11). Furthermore, ectopic expression of PPAR $\gamma$ and CCAAT/enhancer binding protein in cultured myoblasts results in a switch from myogenesis to adipo-

1. Abbreviations used in this paper: aP2, adipocyte P2; GTG, gold thioglucose; PPAR, peroxisome proliferator-activated receptor; STZ, Streptozotocin; UCP-DTA, uncoupling protein diphtheria toxin A. 
genesis (15). Thus, this nuclear receptor appears to function as a dominant activator of fat-cell differentiation through transactivation adipose-specific genes such as aP2; presumably its effects are mediated via the formation of a heterodimeric DNA binding complex with retinoid X receptor $\alpha$ (10). Comparison of the cDNA encoding PPAR $\gamma 2$ with the other PPAR $\gamma$ isoform (PPAR $\gamma 1$ ) reveals two encoded proteins that differ only in their $\mathrm{NH}_{2}$-terminal-30 amino acids $(9,14)$. The two isoforms are derived from the same gene by alternative promoter usage and differential mRNA splicing (16).

Although PPAR $\gamma 2$ mRNA is expressed very early in the course of adipocyte differentiation in vitro $(9,17)$, nothing is known about the physiologic regulation of PPAR $\gamma$ gene expression in vivo. Given the key role that PPAR $\gamma$ seems to play in adipose tissue differentiation, it is critical that physiological regulation of PPAR $\gamma$ gene expression or its potential dysregulation in altered physiologic states, including obesity, be characterized. The results of this study address this issue by quantitation of the in vivo expression of both PPAR $\gamma 1$ and $\gamma 2$ mRNAs in a variety of physiologic and pathophysiologic states in rodents.

\section{Methods}

\section{Animals: experimental protocols}

Care of mice was according to institutional guidelines. Mice were weaned at age $19 \mathrm{~d}$ and housed in conventional cages. They were maintained with a 12-h light/12-h dark photoperiod in a humidityand temperature-controlled room $\left(24^{\circ} \mathrm{C}\right)$. Water and food were available ad libitum, except when noted.

For experiments performed with normal (lean) mice alone, a single inbred strain was employed (FVB-N; Taconic Farms Inc., Germantown, NY). Three different mouse models of genetic or acquired forms of obesity were also studied. Mice with the $o b / o b$ genotype, mice on the C57BL/6J background, and lean controls were obtained from The Jackson Laboratories (Bar Harbor, ME). Gold-thioglucose (GTG) mice that were generated by double injection of gold thioglucose administered to 3-wk-old male Swiss-Albino mice (18) (body wt $67.6 \pm 0.678 \mathrm{~g}$ ) and untreated (lean) Swiss-Albino mice (body wt $39.80 \pm \mathrm{R} 0.202 \mathrm{~g}$ ) were kindly provided by Y. Le Marchand-Brustel (Institut National de la Santé et de la Recherche Médicale, Nice, France). Obese transgenic FVB-N mice with brown adipose tissue deficiency, uncoupling protein diptheria toxin A (UCP-DTA), were generated by brown fat ablation via toxigene expression as previously described (19). Matched lean littermate controls were studied in parallel.

Unless otherwise noted, mice received a regular chow diet (mouse chow 5008; Ralston Purina Co., St. Louis, MO) containing $6.5 \%(\mathrm{wt} / \mathrm{wt})$ fat $(17.3 \%$ of calories), $47 \%$ (wt/wt) carbohydrates $(51 \%$ of calories) and $23.5(\mathrm{wt} / \mathrm{wt})$ protein $(27.6 \%$ of calories). A group of UCP-DTA mice and age-sex-matched lean FVB-N mice were fed the regular chow diet or a diet with higher fat content (Adjusted Calories Western-Type diet 88137; Tecklad Premier Laboratory Diets, Madison, WI), containing $21 \%$ (wt/wt) fat (anhydrous milk fat, $40.8 \%$ of calories), $42.9 \%$ (wt/wt) carbohydrate $(70 \%$ of which was sucrose, $42.2 \%$ of calories), and $19.8 \%$ (wt/wt) protein (17\% of calories) beginning at age $19 \mathrm{~d}$ for a period up until age $12 \mathrm{wk}$. Detailed characterization of these animals was previously published (20). The effects of fasting and refeeding were studied using normal FVB-N mice or obese mice (UCP-DTA, ob/ob, and GTG) with corresponding matched lean controls. For these studies, mice were deprived of chow for the indicated time periods but were allowed ad libitum access to water.

For the induction of insulin-deficient diabetes mellitus, Streptozotocin (STZ, Zanosar@; The Upjohn Co., Kalamazoo, MI) was administered via intraperitoneal injection $(170-180 \mathrm{mg} / \mathrm{kg}$ in $0.9 \% \mathrm{NaCl})$ to normal male FVB-N mice (12 wk). Diabetic mice (age-matched controls) were studied $6 \mathrm{~d}$ after STZ treatment. A separate group of STZdiabetic animals received treatment with insulin (1.5 U of NPH, Eli Lilly and Co., Indianapolis, IN) twice a day, beginning $15 \mathrm{~d}$ after STZ administration for up to $13 \mathrm{~d}$ (until glucose levels were normalized).

\section{Tissues and RNA extraction}

Perigonadal fat pads and other tissues were surgically dissected, rapidly removed, snap frozen in liquid nitrogen, and stored at $-80^{\circ} \mathrm{C}$ until processed. For preparation of isolated mouse adipocytes, freshly obtained perigonadal fat was minced and digested with collagenase. Adipocytes (supernatant) were separated from stromal-vascular cells (pellet) by centrifugation. Cultured 3T3-F442A adipocytes incubated with and without insulin $(5 \mu \mathrm{g} / \mathrm{ml})$ were prepared as previously described (21). Total RNA was extracted using the method of Chomczynski and Sacchi (22). Total RNA from rat liver and hepatic Ito cells was kindly supplied by Scott Friedman (University of California, San Francisco, CA). RNA was quantified by absorbance at $260 \mathrm{~nm}$ in a spectrophotometer (Lambda 2; Perkin-Elmer Spectrometer, South Plainfield, NJ) and its integrity was assessed after electrophoresis in nondenaturing $1 \%$ agarose gels by ethidium bromide staining. $15-\mu \mathrm{g}$ aliquots of adipose tissue RNA were used for determination of PPAR $\gamma$ and $o b$ gene mRNA expression. Two aliquots (200 ng each) were removed from each sample for measurement in $18 \mathrm{~S}$ and aP2 internal control assays. 30- $\mu \mathrm{g}$ aliquots of skeletal-muscle and heart RNA were used for determination of PPAR $\gamma .10-\mu \mathrm{g}$ aliquots of skeletal-muscle and heart total RNA were used for determination of aP2. 200-ng aliquots were removed from each sample for measurement in $18 \mathrm{~S}$ and aP2 (adipose tissue) internal control assays. $25-\mu \mathrm{g}$ aliquots of total RNA from liver were used for measurement of PPAR $\gamma, o b$, and aP2 mRNA. 200-ng aliquots were used in the 18S assay. RNA aliquots of $20 \mu \mathrm{g}, 15 \mu \mathrm{g}$, and $200 \mathrm{ng}$ were used for the tissue distribution study.

\section{RNA analysis}

The solution-hybridization nuclease protection method was used because it offers the highest specificity and quantitative accuracy and is the most suitable method for multiplex mRNA analysis and use with a large number of samples (23).

Specific probe templates. A partial PPAR $\gamma$ cDNA probe was generated by reverse transcriptase-PCR using total RNA from mouse fat as follows: two primers (5'-AACTGCAGGGTGAAACTCTGGGAGATTCTCC-3' and 5'-GGATTCAGCAACCATTGGGTCAGCTCT- $3^{\prime}$ ) were designed to amplify a region that includes $90 \mathrm{bp}$ of the PPAR $\gamma 2$ transcript and 185 bp common to both PPAR $\gamma 1$ and PPAR $\gamma 2$. The PPAR $\gamma$ cDNA PCR-product was ligated into the Pst-I and EcoRI restriction sites of the PGEM-3 (z) cloning vector polylinker. A linearized template for the antisense probe and sense RNA reference was prepared using HindIII and EcoRI, respectively. Use of the antisense probe in an RNase protection assay permits quantitation of PPAR $\gamma$ mRNA transcripts as protected bands of either $273 \mathrm{bp}$ (PPAR $\gamma 2$ ) or 185 bp (PPAR $\gamma 1$ ). The mouse $o b$ probe was prepared from a previously described cDNA clone (24). A 290 bp Pst-I/HindIII cDNA fragment spanning the region from base 110 to 400 in the published sequence (25) was cloned into the pBluescript KS cloning vector polylinker. Template for the antisense probe was prepared by linearizing the vector with HindIII; template for reference RNA was prepared using XbaI. A 450-bp fragment of the mouse aP2 cDNA (gift of Bruce Spiegelman, Dana Farber Cancer Institute, Boston) was subcloned into pBluescript SK. Template for the antisense probe was obtained using $\mathrm{XbaI}$; template for sense RNA reference was obtained using SalI. A 75 bp cDNA corresponding to $18 \mathrm{~S}$ ribosomal RNA (cloned into pBluescript KS, gift of M. Jakubowski, Beth Israel Hospital, Boston, MA) was used as an internal control to correct for variations in RNA amount. The $18 \mathrm{~S}$ ribosomal fraction was chosen because it is unlikely to fluctuate under conditions that affect the expression of mRNAs, since it is transcribed by a distinct polymerase. For sense template, the vector was cut with EcoRI and the antisense 
probe was prepared with SpeI. The identity and orientation of PPAR $\gamma, o b$, and aP2 cDNAs was confirmed by sequencing.

Synthesis of probes and reference RNAs. Antisense probes and reference RNAs were in vitro transcribed from linearized template DNA using bacteriophage Sp6 (Promega Corp., Madison, WI), T7, or T3 (Stratagene, La Jolla, CA) RNA polymerases. PPAR $\gamma, o b$, and aP2 probes were synthesized with high specific activity $(1,500 \mathrm{cpm} / \mathrm{pg})$ using $800 \mathrm{Ci} / \mathrm{mmol}$ UTP $\alpha{ }^{32} \mathrm{P}$ (Dupont-NEN, Boston, MA) as the labeling isotope. The $18 \mathrm{~S}$ probe was synthesized with lower specific activity $(150 \mathrm{cpm} / \mathrm{pg})$ by adding cold UTP. Transcription reactions were stopped by digesting the template DNA with RNase-free DNase I (Boehringer-Mannheim Biochemicals, Indianapolis, IN). Probe and reference RNAs were purified from mononucleotides by ethanol precipitation in the presence of $2.5 \mathrm{M}$ ammonium acetate. The purified reference RNAs were quantified by absorbance at $260 \mathrm{~nm}$ in a spectrophotometer, serially diluted in hybridization solution (4 M GuSCN, O.1 EDTA, pH 7.5) and stored in aliquots at $-80^{\circ} \mathrm{C}$. These aliquots were used for preparing standard curves. $\left[{ }^{32} \mathrm{P}\right]$ UTP incorporation into riboprobes was determined (to ensure that excess amount of probe was used during the hybridization reaction) using aliquots spotted on DE-81 filters (Whatman International, UK). Probe-specific activity was calculated as described $(23,26)$. Probe integrity was determined by autoradiography after electrophoresis on $4 \%$ polyacrylamide/ 7 $\mathrm{mol} \%$ urea denaturing gels (23).

Solution hybridization RNase protection assay. RNA transcripts for PPAR $\gamma, o b, \mathrm{aP} 2$, and ribosomal fraction $18 \mathrm{~S}$ were quantitated using previously described solution hybridization RNase protection assay methods (26). In brief, $\alpha\left[{ }^{32} \mathrm{P}\right]$ UTP-labeled RNA probes were incubated with total RNA samples in a final volume of $25 \mu \mathrm{l}$ of hybridization solution (for the $18 \mathrm{~S}$ probe, final volume was $15 \mu \mathrm{l}$ ) for $12-16 \mathrm{~h}$ at $30^{\circ} \mathrm{C}$. Samples were then incubated for $1 \mathrm{~h}$ at $30^{\circ} \mathrm{C}$ with a mixture of RNase A (40 $\mu \mathrm{g} / \mathrm{ml})$ and RNase T1 $(2 \mu \mathrm{g} / \mathrm{ml})$ (Sigma Chemical Co., St. Louis, MO). To inactivate the nucleases, samples were treated with $10 \%$ SDS $(20 \mu \mathrm{l})$ and $10 \mathrm{mg} / \mathrm{ml}$ Proteinase $\mathrm{K}(5 \mu \mathrm{l})$ for $20 \mathrm{~min}$ at $45^{\circ} \mathrm{C}$ and extracted with phenol:chloroform. After precipitation with ethanol and dissolution in $7 \mu \mathrm{l}$ of gel loading buffer (25\% Ficoll, $0.2 \mathrm{M}$ EDTA, pH 8, 0.25\% bromophenol blue, $0.25 \%$ xylene cyanol), samples were resolved on $5 \%$ non-denaturing polyacrylamide gels $(0.75$ $\mathrm{mm}$ thick) at $300 \mathrm{~V}$ for $2 \mathrm{~h}$. Gels were mounted on $3 \mathrm{M}$ (Whatman Inc., Clifton, NJ) paper and dried. Protected bands were visualized by autoradiography and quantitated by phosphorimager analysis using ImageQuant software (Molecular Dynamics, Sunnyvale, CA).

\section{Protein analysis}

Production of PPAR $\gamma$ antibody. The entire coding region of the PPAR $\gamma 2$ was obtained by PCR using oligonucleotides 5'ATGAGCTCATGGGTGAAACT3' and 5'ATCTCGAGCTAATACAAGTC3'. Restriction sites SstI and XhoI were incorporated at the $5^{\prime}$ and $3^{\prime}$ ends, respectively, and ligated into the polyethylene terephthalates30 a vector (Novagen, Inc., Madison, WI). The resulting polyethylene terephthalates-PPAR $\gamma 2$ was used to generate $5 \mathrm{mg}$ of His-tagged PPAR $\gamma 2$ as described by Novagen instruction. Purified His-PPAR $\gamma 2$ was used to generate a rabbit polyclonal antibody (Research Genetics, Rockville, MD).

SDS-PAGE analysis and Immunoblotting. Mouse fat pads were frozen in liquid nitrogen and stored at $-80^{\circ} \mathrm{C}$ until processed. Protein extracts were obtained after complete polytron homogenization in extraction buffer and $10,000 \mathrm{rpm}$ centrifugation at $4^{\circ} \mathrm{C}$ for $30 \mathrm{~min}$. The extraction buffer was a solution of PBS, $1 \%$ NP- $-40,0.5 \%$ sodium deoxycholate, and $0.1 \%$ SDS. Protease inhibitors were added fresh $(100 \mu \mathrm{g} / \mathrm{ml}$ PMSF, $5 \mu \mathrm{g} / \mathrm{ml}$ pepstatin, $5 \mu \mathrm{g} / \mathrm{ml}$ aprotinin, $5 \mu \mathrm{g} / \mathrm{ml} \mathrm{leu-}$ peptin, $5 \mu \mathrm{g} / \mathrm{ml}$ E64, $10 \mu \mathrm{g} / \mathrm{ml}$ calpain inhibitor-1, $100 \mathrm{mM}$ sodium orthovanadate, and $100 \mathrm{mM}$ sodium fluoride). Protein concentration was assessed by bicinchoninic acid technique (Pierce, Rockford, IL). Proteins were separated via SDS-PAGE, electroblotted onto polyvinyldifluoride membranes (Millipore Corp., Bedford, MA), and immunoblotted using the PPAR $\gamma 2$ antibody.

A modified SDS-PAGE protocol was used to obtain better reso-

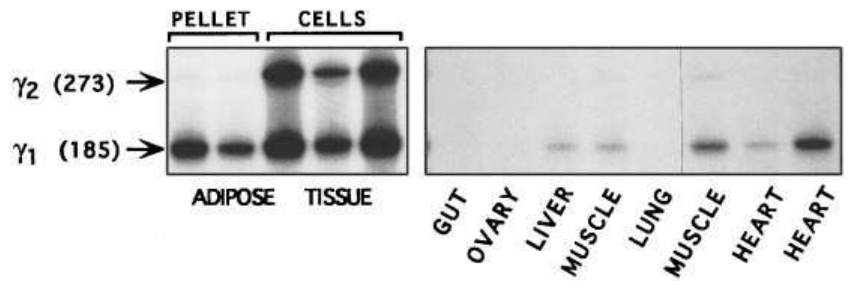

Figure 1. PPAR $\gamma$ mRNA expression in mouse tissues. RNase protection was used to assess the expression of PPAR $\gamma 1$ and $\gamma 2$ mRNAs in mouse adipose tissue as well as several other tissues derived from normal FVB mice. Total RNA (15- $\mu \mathrm{g}$ samples) from isolated adipocytes (cells) or the stromal-vascular cellular fraction (pellet) of epididymal fat pads was analyzed as depicted in the left panel. The right panel depicts the expression pattern of PPAR $\gamma$ in other tissues: gut and ovary (10 $\mu \mathrm{g}$ RNA, each), liver $(20 \mu \mathrm{g})$, skeletal muscle (10 and $25 \mu \mathrm{g})$, lung $(10 \mu \mathrm{g})$, and heart muscle $(10$ and $25 \mu \mathrm{g})$. Protected bands of 273 bases correspond to PPAR $\gamma 2$, bands of 185 bases correspond to PPAR $\gamma 1$.

lution. Briefly, $4 \mathrm{M}$ urea was added to the separating gel (10\%), and the ratio of acrylamide/bisacrylamide was 100:1. Blots were blocked with $1 \%$ casein in Tris-buffered saline buffer for $1 \mathrm{~h}$ at room temperature, incubated with PPAR $\gamma 2$ antibody (1:10 dilution in blocking solution) overnight at $4^{\circ} \mathrm{C}$. Bands corresponding to PPAR $\gamma$ were visualized by enhanced chemiluminescence (Amersham Corp., Arlington Heights, IL).

\section{Statistical analysis}

Regression analysis of data obtained using known amounts of target reference RNAs was used to generate standard curves. Levels of PPAR $\gamma$ and $o b$ mRNAs were calculated and expressed as attomol mRNA/picomol of 18S RNA. Levels of aP2 mRNA were calculated and expressed as attomol $/ \mu \mathrm{g}$ of total RNA. All results are presented as means \pm SEM. Statistical significance was assessed by ANOVA and unpaired Student's $t$ test. The level of significance was set at $P<0.05$.

\section{Results}

\section{Tissue distribution of PPAR $\gamma$ isoform expression}

We developed a sensitive RNase protection assay that allows for precise and specific quantitation of mRNAs encoding PPAR $\gamma 2$ and $\gamma 1$ isoforms. When we examined RNA extracted from mouse adipose tissue, similar amounts of both PPAR $\gamma 2$ and PPAR $\gamma 1$ mRNAs were detected. To examine which isoform(s) were expressed in adipocytes per se, we analyzed RNA extracted from both isolated mouse adipocytes

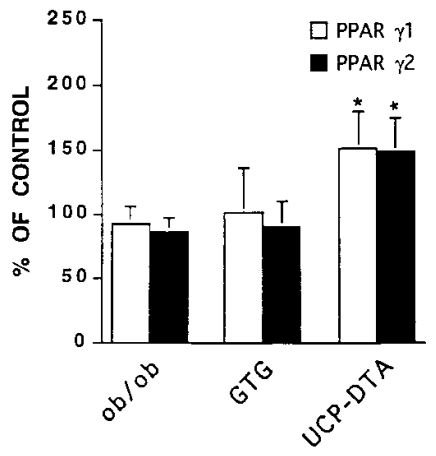

Figure 2. PPAR $\gamma$ mRNA expression in different murine models of obesity. Expression of PPAR $\gamma 1$ and $\gamma 2$ mRNAs in mouse white fat RNA (epididymal fat pads) was assessed in mice with three forms of obesity (ob/ob, $n=4, G T G$, $n=3, U C P-D T A, n=5)$ in the fed state. Results are expressed as the mean \pm SEM percentage of mean values obtained using adipose tissue RNA derived from equal numbers of the appropriate age-sex-matched lean control mice. *UCP-DTA vs control, $P<0.05$. 

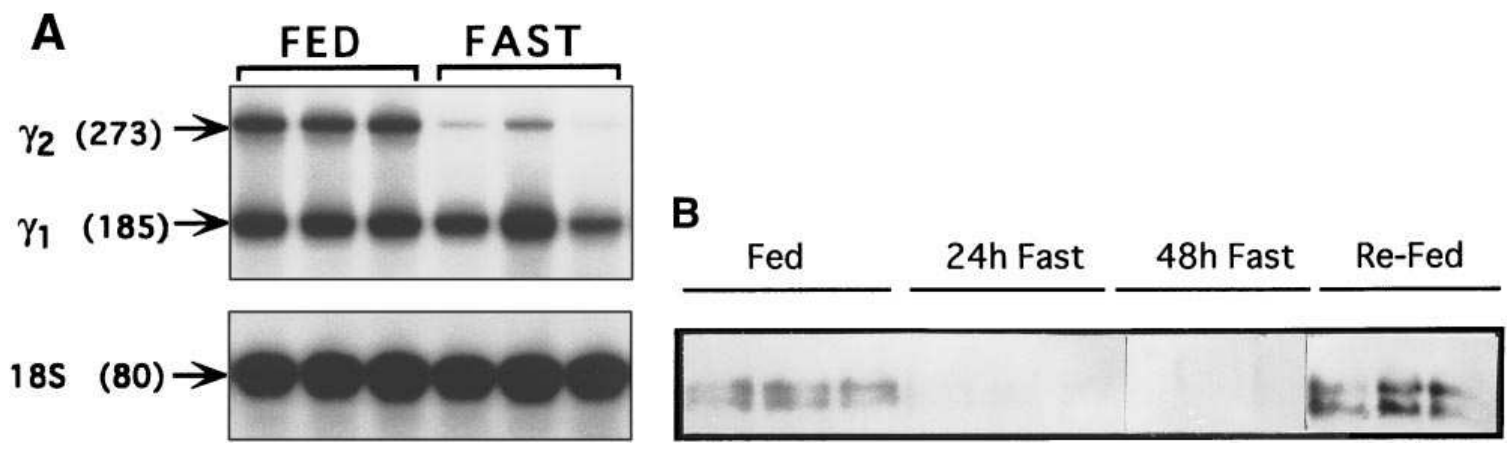

$18 S$

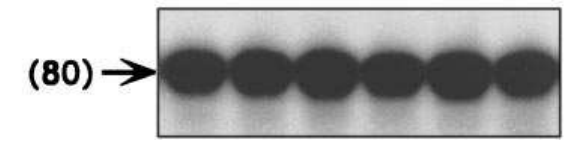

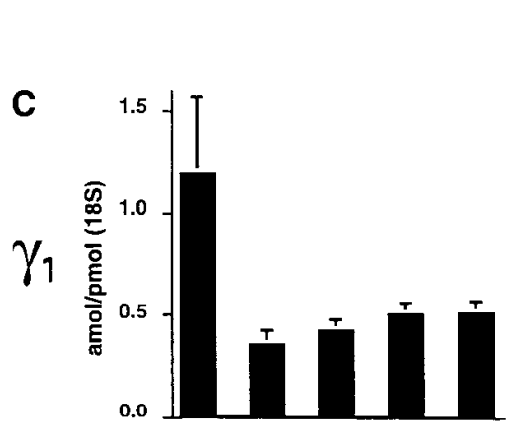
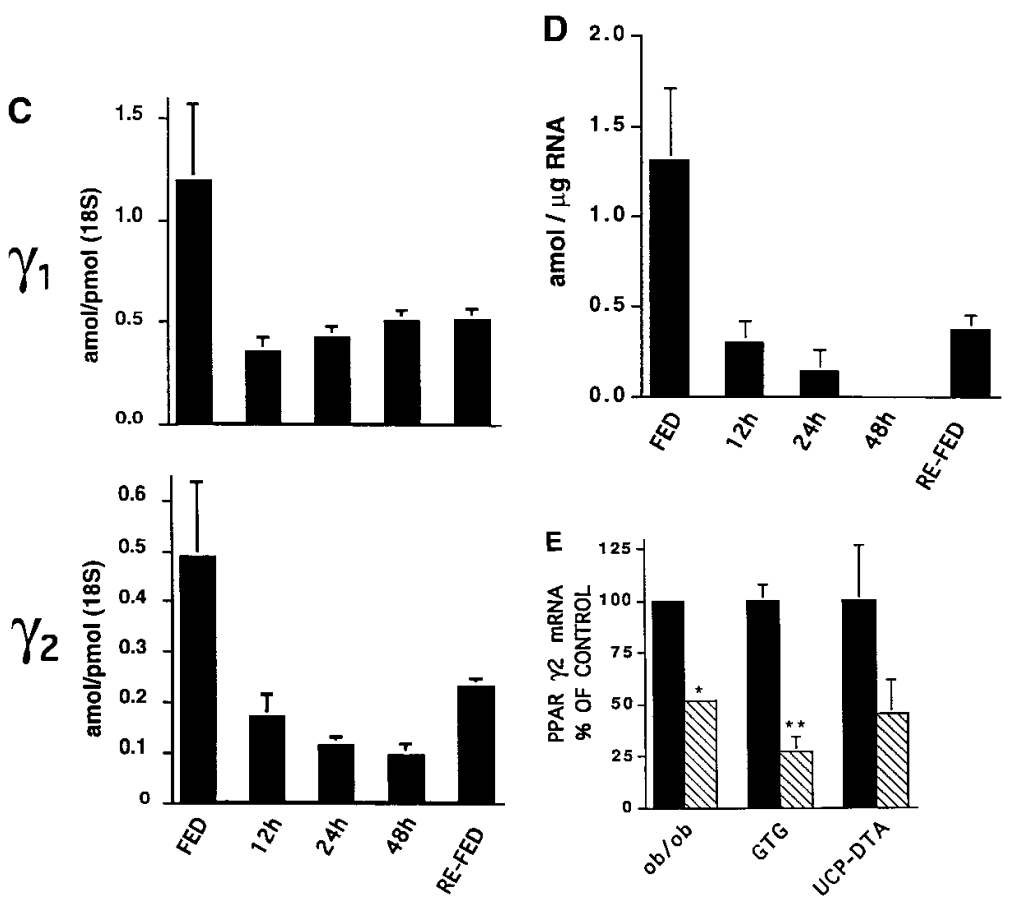

Figure 3. Effects of fasting on adipose tissue gene expression. (A) Fasting reduces PPAR $\gamma$ mRNA expression in adipose tissue. This example autoradiogram shows results of RNase protection analysis obtained using RNA $(15 \mu \mathrm{g})$ extracted from white adipose tissue (parametrial) obtained from 3 fed and 3 fasted ( $24 \mathrm{~h}$ ) female FVB mice. PPAR $\gamma 1$ and $\gamma 2$ mRNAs are visualized as protected bands of 185 and 273 bases, respectively. The expression level of $18 \mathrm{~S}$ ribosomal RNA (80-base protected band) was determined and used as an internal control to correct for minor variation in total RNA amount. (B) Immunoblotting with PPAR $\gamma 2$ polyclonal antibody. Samples represent proteins derived from mice adipose tissue in fed state, fasted for 24 and $48 \mathrm{~h}$, and refed for $24 \mathrm{~h}$ ( $n=6$ per group). Proteins were separated by SDSPAGE, followed by Western immunoblotting. The double bands detected are likely due to posttranslational modification events (Hu and Spiegelman, unpublished data). (C) Time course of fasting and refeeding effect on PPAR $\gamma$ isoform expression. Total RNA was extracted from epididymal fat pads obtained from male FVB mice that were either fed ad libitum, deprived of food for the indicated time periods, or refed for $24 \mathrm{~h}$ after a $48 \mathrm{~h}$ fast $(n=5-7$ mice, each). RNase protection was used to quantitate the expression of PPAR $\gamma 1$ and $\gamma 2$ mRNAs and $18 \mathrm{~S}$

RNA relative to known amounts of in vitro transcribed sense RNA templates. Results (mean \pm SEM) are expressed as amol of PPAR $\gamma$ mRNA/ pmol 18S RNA. Statistically significant differences were observed for both PPAR $\gamma 1$ (ANOVA, $P=0.03$ ) and PPAR $\gamma 2$ (ANOVA, $P=0.003$ ). $(D)$ Effects of fasting on the expression of $o b$ mRNA. The RNA samples used as described for $C$ (above) were used to evaluate $o b$ mRNA expression by RNase protection. Results are expressed as amol of $o b$ mRNA/ $\mu \mathrm{g}$ of total RNA. Statistically significant differences were found associated with fasting and refeeding (ANOVA, $P<0.0001$ ). (E) Regulation of PPAR $\gamma 2$ mRNA by fasting in different models of obesity. The effects of $24 \mathrm{~h}$ fasting (diagonal-striped bars) on PPAR $\gamma 2$ mRNA expression in white adipose tissue were assessed using $o b / o b(n=4)$, GTG $(n=$ $3)$, and UCP-DTA $(n=5)$ mice. Results are expressed as a percentage of values obtained using equal numbers of matched obese mice fed ad libitum (solid bars). *fasted vs fed, $P=0.007 ; * *$ fasted vs fed, $P=0.017$.

and residual stromal-vascular cells present in the pellet after adipocyte isolation. As shown in Fig. 1, the stromal-vascular fraction contained only PPAR $\gamma 1$ mRNA, whereas mature adipocytes expressed similar high levels of both PPAR $\gamma 1$ and PPAR $\gamma 2$ mRNAs.

In comparison with levels in white adipose tissue, both PPAR $\gamma 1$ and $\gamma 2$ mRNAs were expressed at similar levels in brown adipose tissue; both isoforms were also detected in RNA from the adrenal gland (not shown). PPAR $\gamma 1$ mRNA was expressed in spleen and also at low levels in liver, skeletal muscle, and heart. A less intense PPAR $\gamma 2$ mRNA signal ( $13 \%$ of that seen in adipose tissue) was also detected in skeletal muscle (Fig. 1). To determine whether the PPAR $\gamma 2$ signal in skeletal muscle was entirely the result of contamination with fat cells, $10-\mu \mathrm{g}$ aliquots of skeletal muscle and heart total RNA were assayed for aP2 mRNA expression. Very low levels of aP2 mRNA were detected in both tissues. Levels in heart (a tissue that does not have PPAR $\gamma 2$ mRNA expression) were higher than in skeletal muscle. If the PPAR $\gamma 2$ signal detected in $30 \mu \mathrm{g}$ of muscle mRNA was entirely due to fat contamination, $4.1 \mu \mathrm{g}$ of adipose tissue mRNA would be needed. This amount of adipose tissue generates a much more intense signal of aP2 mRNA than we detected. These data strongly suggest that PPAR $\gamma 2$ mRNA is expressed to some degree in skeletal muscle, although considerably less than is seen in fat.

\section{PPAR y expression in rodent models of obesity}

To explore the hypothesis that obesity might be associated with abnormal adipose tissue expression of PPAR $\gamma$, we compared three different rodent models that represent genetic $(o b /$ $o b$ ), acquired (GTG), and transgenic (UCP-DTA) forms of obesity with their lean controls (also matched for age and sex). The protected RNA bands corresponding to both PPAR $\gamma 1$ and PPAR $\gamma 2$ transcripts were quantitated, normalized for mi- 
nor differences in RNA input (18S RNA), and plotted against standard curves generated using known amounts of target PPAR $\gamma$ RNA. When the data derived from obese mice were expressed as a percentage of values obtained using the corresponding lean controls, no differences in the amount of either PPAR $\gamma$ isoform mRNAs were detected in $o b / o b$ or GTG obese mice (Fig. 2). In contrast, UCP-DTA mice showed a modest increase in expression of PPAR $\gamma 1$ and $\gamma 2$ mRNA ( $57 \%$ and $59 \%, p=0.023$ and $p=0.0158$, respectively) compared to lean FVB controls. Thus, when expressed relative to total RNA amount, obesity is not associated with substantial changes in adipocyte PPAR $\gamma$ gene expression.

\section{Effect of fasting and refeeding on PPAR $\gamma$ expression}

As shown in Fig. $3 A$, initial results obtained with female FVB mice that were food deprived for $24 \mathrm{~h}$ indicated that the expression of PPAR $\gamma 2$ in adipose tissue was markedly reduced with a more modest decrease in PPAR $\gamma 1$ expression. As expected, levels of 18S RNA (per microgram of total RNA) remained constant. In a second series of experiments that were conducted using male FVB mice, we observed that fasting was associated with a progressive decline in PPAR $\gamma 2$ expression, reaching a maximum $82 \%$ reduction after $48 \mathrm{~h}$ (Fig. $3 \mathrm{C}$ ). PPAR $\gamma 1$ mRNA levels were reduced by $60 \%$ after $48 \mathrm{~h}$ of fasting. After $24 \mathrm{~h}$ of refeeding, PPAR $\gamma 2$ mRNA levels were partially restored to normal. Immunoblotting analysis of adipose tissue protein extracts using a PPAR $\gamma 2$ antibody supported the RNA data. Thus, fasting was associated with a marked decrease in PPAR $\gamma 2$ protein levels (Fig. $3 B$ ).

To determine the extent of changes in PPAR $\gamma$ gene expression induced by fasting relative to changes in the expression of other fat-specific genes, RNase protection analysis of $o b$ and aP2 mRNA expression in adipose tissue was performed using the same RNA samples used for PPAR $\gamma$ analysis. As shown in Fig. $3 D, o b$ mRNA levels were dramatically reduced by fasting and partially restored by refeeding, following a pattern similar to that for PPAR $\gamma 2$. The specificity of these changes was confirmed since aP2 mRNA levels were unaffected under these experimental conditions (not shown). These findings indicate that both PPAR $\gamma 2$ and $o b$ mRNA expression are tightly regulated in parallel by in vivo nutritional deprivation.

In addition, we assessed the effects of fasting ( $24 \mathrm{~h})$ on PPAR $\gamma 2$ mRNA expression in adipose tissue from the three obese mouse models. Fasting was associated with significantly reduced PPAR $\gamma 2$ mRNA expression in both $o b / o b$ and GTG mice (Fig. $3 E$ ). A similar trend was evident in UCP-DTA mice as well. These results suggest that regulation of PPAR $\gamma$ gene expression by fasting is preserved in obesity.

We evaluated whether similar regulation of PPAR $\gamma$ mRNA expression was observed in skeletal muscle or heart. No differences were observed in the expression of PPAR $\gamma 1$ mRNA in heart or skeletal muscle during fasting or refeeding compared to the fed state (data not shown). In contrast, PPAR $\gamma 2$ mRNA in skeletal muscle showed nutritional regulation, modestly decreasing after $48 \mathrm{~h}$ fasting and increasing with refeeding $(25 \%$ fall, $P=0.05)$.

Effects of insulin on PPAR y gene expression: the insulindeficient streptozotocin model

Normal FVB mice were treated with STZ to induce insulindeficient diabetes mellitus. The mean value of plasma glucose levels (fed) in untreated control mice was $179.8 \mathrm{mg} / \mathrm{dl}$. The mean glucose level in STZ-treated mice was $314.5 \mathrm{mg} / \mathrm{dl}$. More extreme hyperglycemia (longer term diabetes or higher dose STZ) was associated with a marked decrease in fat pad size, which precluded RNA extraction. Several mice with longer term diabetes received insulin therapy to restore glucose levels to normal (mean $108 \mathrm{mg} / \mathrm{dl}$ ). Expression of PPAR $\gamma 1$ and $\gamma 2$ mRNAs in adipose tissue was examined by RNase protection assay and quantitated by phosphoimaging technology. As shown in Fig. 4, diabetes was associated with an $80 \%$ reduction in the level of expression of PPAR $\gamma 2$. There was a less pronounced $(60-70 \%)$ decline in the level of PPAR $\gamma 1$ mRNA levels $(P<0.05$, not shown). Insulin administration restored expression of PPAR $\gamma 1$ and $\gamma 2$ mRNAs to levels not significantly different from those seen in the nondiabetic animals. These data demonstrate that in the insulinopenic diabetic state, there is a reduction in the expression of both isoforms of PPAR $\gamma$ and that PPAR $\gamma$ mRNA levels can be restored to normal by insulin replacement.

To further characterize the effect of insulin on PPAR $\gamma$ gene expression, we examined the levels of $\gamma 1$ and $\gamma 2$ mRNAs in fully differentiated 3T3F442A adipocytes cultured in media with or without $5 \mu \mathrm{g} / \mathrm{m} \mathrm{l}$ insulin for $21 \mathrm{~d}$. Cells incubated with insulin showed a 2.0- and 1.7-fold increase in the expression of PPAR $\gamma 2(P<0.01)$ and PPAR $\gamma 1(P<0.05)$, respectively (data not shown). Taken together, the results described above indicate that insulin could have a key role as a specific stimulus of PPAR $\gamma$ gene expression in adipose cells.

\section{High fat vs low fat diet}

Effect of a high fat diet on PPAR y expression in adipose tissue (Fig. 5). The PPAR $\alpha$ isoform is known to be activated by fatty acids $(27,28)$. PPAR $\gamma$ has also been suggested to be activated by certain polyunsaturated fatty acids (11). In addition to binding and transactivation, which might potentially be mediated by lipids, we sought to determine whether dietary fat might regulate PPAR $\gamma$ at the level of gene expression. To address this issue, we studied both normal and obese (UCPDTA) FVB mice that had received either regular chow (17\% of calories from fat) or a diet high in fat ( $41 \%$ of calories) from age $19 \mathrm{~d}$ to $12 \mathrm{wk}$. RNase protection analysis revealed that exposure of normal FVB mice to the high fat diet resulted in a modest increase in both PPAR $\gamma 1(33 \%, P<0.05)$ and PPAR

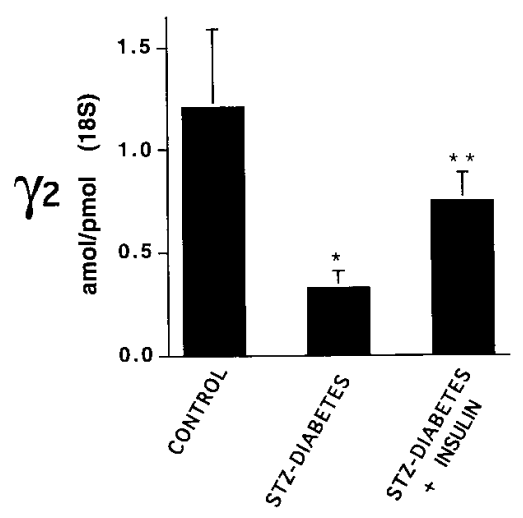

Figure 4. Regulation of PPAR $\gamma 2$ mRNA expression by STZ diabetes and insulin. Three groups of male FVB mice were compared: normal FVB mice (control, $n=5)$, mice rendered diabetic by treatment with streptozocin (STZ-diabetes, $n=8$ ), and STZ-diabetic mice which had received insulin for several days to normalize plasma-

glucose levels (STZ-diabetes + insulin, $n=4)$. PPAR $\gamma 2$ mRNA expression in epididymal fat pads was assessed. Results are expressed as amol PPAR $\gamma 2 \mathrm{mRNA} / \mathrm{pmol} 18 \mathrm{~S}$ RNA. *diabetic vs control, $P=$ $0.018 ; *$ insulin treatment vs STZ-diabetes, $P=0.024$. 


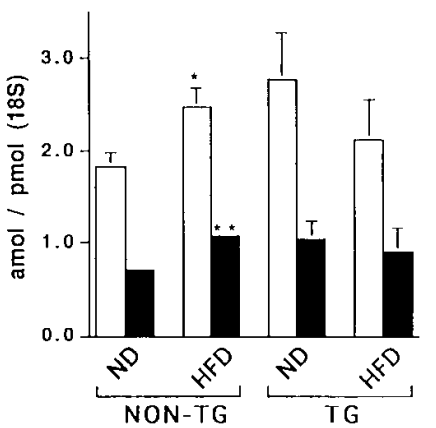

Figure 5. Effect of high fat diet on PPAR $\gamma$ mRNA expression in adipose tissue. The effects of a high fat diet $(H F D$ $41 \%$ of calories from fat, 12 wk), compared to regular chow $(N D, 17 \%$ of calories from fat), were assessed using two groups of mice: normal female FVB mice $(N O N-T G)$ and age-sex-matched transgenic obese UCP-DTA mice $(T G)$. The expression of both PPAR $\gamma 1$ (open bars) and PPAR $\gamma 2$ (solid bars) mRNAs in parametrial white fat were determined. Results are expressed as amol of PPAR $\gamma$ mRNA/pmol 18S RNA. Each bar represents the mean \pm SEM of values obtained using $4-5$ mice. $* \mathrm{HFD}$ vs ND, $P=0.04$, **HFD vs ND, $P=0.002$. Not shown, TG-ND vs NON-TG-ND, $P=0.03$ for PPAR $\gamma 1 ; P=0.04$ for PPAR $\gamma 2$.

$\gamma 2(50 \%, P=0.002)$ in adipose tissue, reaching levels similar to that of UCP-DTA mice on the chow diet. In contrast, no further increase in adipose tissue PPAR $\gamma$ mRNA levels were observed in the obese mice exposed to the high fat diet.

Induction of PPAR $\gamma 2 \mathrm{mRNA}$ in liver of obese mice by high fat feeding. Given that PPAR $\gamma$ expression in adipose tissue from normal mice was influenced by an increase in dietary fat and the fact that low levels of PPAR $\gamma 1$ mRNA were detected in liver, we assessed the effect of high fat feeding on PPAR $\gamma$ gene expression in this tissue. Livers were obtained from the same mice used to study the effect of high fat feeding on adipose tissue PPAR $\gamma$ expression. In lean normal FVB mice, hepatic expression of PPAR $\gamma 1$ was not affected by high fat feeding and PPAR $\gamma 2$ remained undetectable. In obese mice, PPAR $\gamma 1$ mRNA levels were also unaffected by high fat feeding; however, this dietary manipulation caused a surprising induction of PPAR $\gamma 2$ expression (Fig. $6 A$ ). Quantitation of hepatic PPAR $\gamma 2$ mRNA expression under these circumstances revealed that mean levels (per microgram total RNA) were approximately $10 \%$ of mean levels in adipose tissue from lean normal mice (not shown). Since PPAR $\gamma 2$ is implicated in initiating the complete program of adipocyte differentiation (9), we determined whether the hepatic expression of PPAR $\gamma 2$ in obese mice might induce the expression of other fat-specific genes. RNase protection analysis of liver RNA was performed using the $o b$ and aP2 probes. $o b$ mRNA expression was not detectable in the liver of these animals (not shown) and only trace amounts of aP2 mRNA were present without differences among groups (Fig. $6 \mathrm{~B}$ ). The levels detected in liver were estimated to be $0.1 \%$ of aP2 mRNA levels in white fat (Fig. $6 B$ ). These findings exclude the possibility that liver RNA from high fat-fed obese mice was contaminated with adipose tissue RNA, and confirm the specificity of the PPAR $\gamma 2$ mRNA induction in obese mouse liver by the high fat diet.

\section{Discussion}

The PPAR family of nuclear receptors is comprised of three distinct isoforms $(\alpha, \delta, \gamma)$ with different and specific tissue distribution. PPAR $\alpha$ is expressed predominantly in tissues that undergo peroxisomal proliferation such as liver, kidney, and heart and is activated by several hypolipidemic drugs and fatty acids, resulting in induction of the expression of enzymes involved in peroxisomal fatty acid $\beta$ oxidation $(27,29,30)$. PPAR $\delta$ is expressed ubiquitously, is activated by fatty acids, and has no known specific ligand(s) (31). Although it has been suggested that PPAR $\delta$ could play an important role in the adipogenic effect of overfeeding (32), no clear physiologic function has been described (13). PPAR $\gamma$ is a relatively new member of the PPAR family that was recently suggested to have a key role in the regulation of gene expression in adipose tissue. Thus, PPAR $\gamma$ has been implicated in mediating the expression of fat-specific genes and in activating the program of adipocyte differentiation in vitro $(9,11)$. Consequently, activation of PPAR $\gamma$ could constitute an important part of the molecular mechanism behind the adipogenic effect of overfeeding. In overexpression studies, it has most recently been shown that PPAR $\gamma$ has the greatest adipogenic action, that PPAR $\alpha$ also has some ability to stimulate adipogenesis, but PPAR $\delta$ has no such ability even when activated with multiple compounds (33). Since PPAR $\gamma$ is the most important member of this family for regulation of adipogenesis, the aim of the present work was to determine the physiological regulation of PPAR $\gamma$ gene expression in vivo and its potential dysregulation in altered physiologic states including obesity and insulin-deficient streptozotocin-induced diabetes.

Analysis of tissue distribution revealed that both PPAR $\gamma 1$ and $\gamma 2$ mRNAs were abundantly expressed in white and
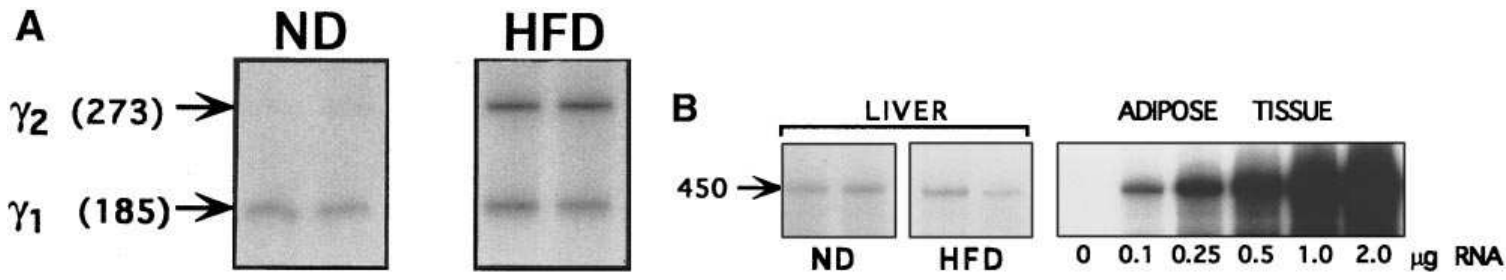

Figure 6. Effect of high fat diet on PPAR $\gamma$ mRNA expression in liver. (A) PPAR $\gamma 2$ mRNA expression is induced in the livers of obese UCPDTA mice on a high fat diet. UCP-DTA mice received either regular chow $(N D)$ or the high fat diet $(H F D)$ as described in Fig. 5. The example autoradiograms show results of RNase protection analysis performed using $20 \mu \mathrm{g}$ total RNA from the livers of two mice in each group. Similar results were obtained with three additional mice in each group. No PPAR $\gamma 2 \mathrm{mRNA}$ expression was detected in livers from lean FVB mice after exposure to the high fat diet (not shown). (B) Assessment of aP2 mRNA expression in liver (left panels). Liver RNA samples ( $25 \mu \mathrm{g})$ from obese UCP-DTA mice exposed to regular chow $(N D)$ or the high fat diet $(H F D)$ were analyzed by RNase protection to determine levels of aP2 mRNA expression (450 base protected band). The example autoradiogram shows results for two mice in each group. Analysis of aP2 mRNA levels using different amounts of total RNA from white fat (right panel) indicates that hepatic aP2 expression levels are very low relative to expression in adipose tissue. 
brown adipose tissue. When the adipose tissue was analyzed as separate fractions, mRNA corresponding to both isoforms was abundantly present in mature isolated adipocytes. PPAR $\gamma 2$ was not detected in the stromal-vascular fraction from adipose tissue, although high levels of PPAR $\gamma 1$ mRNA were present. These data clearly show that not only is PPAR $\gamma 2$ expressed in adipose cells, but the PPAR $\gamma 1$ isoform is also detected in substantial amounts. This differs somewhat from the observation of Tontonoz et al. (11) that PPAR $\gamma 2$ is the only isoform expressed cultured in adipose cells, perhaps representing a difference between tissues and cultured cells. Recent data reported by Tontonoz et al. showed that transfection of a truncated form of PPAR $\gamma 2$ that lacks $127-\mathrm{NH}_{2}$-terminal amino acids (retaining the DNA and ligand binding domains) mediates adipogenic differentiation of fibroblasts at an even higher rate than wild-type PPAR $\gamma 2$ and furthermore, overexpression studies indicate that both PPAR $\gamma 2$ and PPAR $\gamma 1$ are competent to stimulate adipogenesis (11). Taken together, these observations suggest that both PPAR $\gamma 2$ and PPAR $\gamma 1$ might play an important role in the initiation or determination of the adipocyte program in vivo. The physiologic relevance of low level PPAR $\gamma 1$ mRNA expression in muscle, heart, liver, spleen, and kidney remains to be determined. However, some evidence suggests that thiazolidinediones, a new class of insulin sensitizers with proven antidiabetic activity, improve hepatic (34) and muscle (35) insulin resistance. Recent reports also show that thiazolidinedione derivatives are high affinity ligands for PPAR $\gamma$ (36). Therefore, the insulin sensitizing effect of thiazolidinediones in muscle and liver may be due to activation of the PPAR $\gamma 1$ and $\gamma 2$ isoforms that we have detected in these tissues. Similarly, the activation of PPAR $\gamma$ in muscle and liver by its endogenous ligand could have an important role in maintaining the insulin sensitivity of these tissues.

Adipose tissue levels of PPAR $\gamma 1$ and $\gamma 2$ mRNA were not altered in the $o b / o b$ mice or in GTG-induced obesity, and were only modestly increased in obese brown adipose tissue-deficient UCP-DTA mice. These findings suggest that the increased adiposity characteristic of these animal models is not likely to result from altered PPAR $\gamma$ gene expression. On the other hand, the contribution of new fat cell formation to obesity (adipocyte hyperplasia) may well require the presence of PPAR $\gamma$. This role could readily be subserved by PPAR $\gamma 1$ expressed in preadipocytes or adipocyte precursors since the stromal-vascular fraction of adipose tissue is known to contain these cells (37). To the extent that micromolar fatty acid concentrations may activate PPAR $\gamma(31)$, a vicious cycle might ensue whereby obesity promotes increases in free fatty acid levels, which lead to further adipogenesis via PPAR $\gamma$ transactivation.

In contrast to the relative lack of altered PPAR $\gamma$ expression associated with obesity, fasting provoked a substantial decrease in the levels of both PPAR $\gamma 1$ and $\gamma 2$ mRNAs and corresponding protein levels in adipose tissue from normal mice. Similar effects of fasting on PPAR $\gamma$ mRNAs were noted in all three models of obesity. Thus, PPAR $\gamma$ expression is physiologically regulated by food intake and this regulation is conserved in the obese animal models that we studied. It is important to note that aP2 mRNA expression was not significantly altered by fasting. This finding indicates that effects on PPAR $\gamma$ mRNA levels do not reflect a generalized decrease in fat tissue gene expression. Given that PPAR $\gamma 2$ is likely to play a prominent role in the upregulation of aP2 expression, which occurs during adipocyte differentiation (9), the lack of change in aP2 mRNA at a time when PPAR $\gamma 2$ mRNA and PPAR $\gamma$ protein levels have decreased by severalfold is somewhat surprising. PPAR $\gamma$ is likely to modulate the expression of many other genes in adipose tissue, although the only other known example is phosphoenolpyruvate carboxykinase which mediates glycerol synthesis (38). It is plausible that $\operatorname{PPAR} \gamma$-responsive genes that influence metabolism within the fat cell (such as phosphoenolpyruvate carboxykinase) may be regulated not only by changes in the circulating or intracellular levels of potential PPAR $\gamma$ ligands, but also by changes in the levels of PPAR $\gamma$ expression such as we observed with fasting.

Regulation similar to that seen with fasting was also observed in the insulin-deficient (streptozotocin) diabetic mice, where adipose tissue shows suppressed PPAR $\gamma 1$ and $\gamma 2$ mRNA expression with partial restoration during insulin treatment. Furthermore, insulin stimulation of 3T3F442A adipocytes induced an increase in the expression of PPAR $\gamma 1$ and $\gamma 2$ mRNAs. These data suggest that insulin, a well known adipogenic factor, could directly or indirectly (21) induce PPAR $\gamma$ expression in adipose tissue. The effect of insulin on another PPAR family member is apparently different. Thus, insulin has been demonstrated to have an inhibitory effect on PPAR $\alpha$ mRNA expression in liver. In the absence of insulin, PPAR $\alpha$ is increased (39), activating peroxisomal $\beta$ oxidation (30) and an alternative pathway for the use of fatty acids, involved in ketogenesis (40). These data together suggest that insulin could be an important hormone regulating different pathways for the utilization of fatty acids through the activation or inactivation of different PPAR family members in different tissues. In the fed state, insulin would stimulate the expression of PPAR $\gamma$ in adipose tissue at the same time that it would tend to inhibit hepatic expression of PPAR $\alpha$. In the fasted and insulin-deficient diabetic states, expression of PPAR $\gamma$ in adipose tissue would be downregulated, while in liver, $\operatorname{PPAR} \alpha$ would induce the expression of enzymes involved in fatty acid oxidation.

Interestingly, levels of leptin mRNA appeared to parallel the decline in PPAR $\gamma$ gene expression during fasting. Furthermore, Frederich et al. (24) and MacDougald et al. (41) have demonstrated that leptin expression is markedly downregulated during insulin deficient diabetes. In addition, leptin mRNA levels are upregulated in vivo under hyperinsulinemiceuglycemic clamp conditions and may also be directly stimulated by insulin in vitro using isolated adipocytes (42). These observations suggest that changes in the level of PPAR $\gamma$ expression could cause or contribute to the regulation of leptin expression, or that both genes are responding to a common pathway or transacting factor(s). Further studies will be required to address the hypothesis that the $o b$ gene promoter may be regulated by PPAR $\gamma$.

The effects of high fat feeding were studied in both control and obese UCP-DTA mice. We observed that the PPAR $\gamma 2$ mRNA in adipose tissue was modestly induced in fat-fed control mice to levels that were similar to obese mice on a normal diet. On the other hand, no further increase in adipose tissue PPAR $\gamma$ expression was evident in fat-fed obese mice. Interestingly, these results appear to correlate with relative differences in fat cell size: FVB mice on the chow diet have mean values of $0.4 \mu \mathrm{g}$ lipid per cell, and in fat-fed normal FVB mice, mean adipocyte size is increased to $0.73 \mu \mathrm{g} / \mathrm{cell}$. This increased 
size is similar to mean values obtained with chow-fed UCPDTA mice $(0.8 \mu \mathrm{g} /$ cell $)(U$. Frevert and B.B. Kahn, unpublished observations). Therefore, it is reasonable to speculate that PPAR $\gamma$ gene expression might be stimulated by increased cellular lipid content until a determined threshold is reached. This model of saturable metabolic regulation has been observed with other members of the PPAR family (43). Thus, it is possible that other factors may act to prevent further induction of PPAR $\gamma$ mRNA in the obese mice. Indeed, we previously observed that high fat feeding of obese mice causes a substantial increase in TNF $\alpha$ mRNA expression (20). This may serve as an adaptive mechanism to slow down the further accumulation of fat stores since TNF $\alpha$ is known to inhibit adipogenesis in vitro $(44,45)$. Further studies will be required to address the hypothesis that PPAR $\gamma$ gene expression could be inhibited through a TNF-mediated mechanism.

Most striking was the finding that high fat feeding results in de novo expression of PPAR $\gamma 2$ mRNA in liver with no apparent increase in low levels of PPAR $\gamma 1$ mRNA detected in this tissue. Since alternative promoters direct the synthesis of PPAR $\gamma 1$ vs $\gamma 2$ mRNA synthesis (16), these data suggest that markedly increased levels of circulating fatty acids (which occur in this physiologic context) may serve to specifically activate the $\gamma 2$ promoter in a tissue not normally expressing this isoform. Under these circumstances, we failed to detect expression of leptin mRNA and there was no change in trace levels of aP2 mRNA. Therefore, the level of PPAR $\gamma$ expression achieved in the liver of fat-fed obese mice (which was approximately $10 \%$ of that in white adipose tissue) was not sufficient to initiate the program of adipocyte differentiation.

In summary, we used a sensitive RNase protection assay to detect and quantitate levels of PPAR $\gamma 1$ and $\gamma 2$ in mice. Levels of adipose tissue PPAR $\gamma 1$ or $\gamma 2$ mRNAs were not affected by obesity in the $o b$ and GTG animal models. However, ablation of brown adipose tissue was associated with a modest increase in PPAR $\gamma$ mRNA expression associated with marked obesity. The expression of adipose tissue PPAR $\gamma 1$ and $\gamma 2$ mRNA and PPAR $\gamma$ protein were downregulated by fasting and insulindeficient diabetes (along with leptin expression). Exposure of normal mice to a high fat diet resulted in the modest induction of PPAR $\gamma 2$ mRNA and enlargement of adipose cells to an extent that was comparable to chow-fed obese mice. Administration of a high fat diet to UCP-DTA obese mice did not induce a further increase in adipose tissue PPAR $\gamma$ expression, but it resulted in specific induction of hepatic PPAR $\gamma 2$ mRNA expression. These results suggest that in vivo modulation of PPAR $\gamma$ gene expression provides an additional level of regulation for the control of adipocyte development and function.

\section{Acknowledgments}

We are especially grateful to Yannick Le Marchand-Brustel (Institut National de la Santé de la Recherche Médicale, Nice, France) for access to GTG-obese mice, to Moshe Jakubowski (Beth Israel Hospital) for technical advice, to Robert Frederich (Beth Israel Hospital) for the $o b$ probe, and to Uli Frevert and B.B. Kahn for unpublished data.

This work was supported by National Institutes of Health (NIH)National Institute of Arthritis, Diabetes, and Digestive and Kidney Diseases grant RO1 45878 (to D.E. Moller), RO1 DK-46930, DK28082 (to J.S. Flier), and the Boston Obesity and Nutrition Center (NIH- P30 DK-46200). A. Vidal-Puig is supported by the Paul Dudley White Fellowship Award from the American Heart Association (MA affiliate).

\section{References}

1. Flier, J.S. 1995. The adipocyte: storage depot or node on the energy information superhighway. Cell. 80:15-18.

2. Van Itali, T.B. 1979. Obesity: adverse effects on health and longevity. Am. J. Clin. Nutr. 32:2723-2733.

3. Manson, J.E., W.C. Willett, M.J. Stampfer, G.A. Colditz, D.J. Hunter, S.E. Hankinson, C.H. Hennekens, and F.E. Speizer. 1995. Body weight and mortality among women. N. Engl. J. Med. 333:677-685.

4. Spiegelman, B., and H. Green. 1980. Control of specific protein biosynthesis during the adipose conversion of 3T3 cells. J. Biol. Chem. 255:8811-8818.

5. Spiegelman, B.M. 1988. Regulation of gene expression in the adipocyte: implication for obesity and proto-oncogene function. Trends Genet. 4:203-207.

6. Christy, R.J., V.W. Yang, J.M. Ntambi, D.E. Geiman, W.H. Landschulz, A.D. Friedman, Y. Nakabeppu, T.J. Kelly, and M.D. Lane. 1989. Differentiation-induced gene expression in 3T3-L1preadipocytes: CCAAT/enhancer binding protein interacts with and activates the promoters of two adipocyte specific genes. Genes \& Dev. 3:1323-1335.

7. MacDougald, O.A., P. Cornelius, R. Liu, and M.D. Lane. 1995. Insulin regulates transcription of the CCAAT/enhancer binding protein $(\mathrm{C} / \mathrm{EBP})$ alpha, beta, delta genes in fully differentiated 3T3-L1 adipocytes. J. Biol. Chem. 270:647-654.

8. Lin, F.T., and M.D. Lane. 1994. CCAAT/enhancer binding protein alpha is sufficient to initiate the 3T3-L1 adipocyte differentiation program. Proc. Natl. Acad. Sci. USA. 91:8757-8761.

9. Tontonoz, P., E. Hu, R. Graves, A. Budavari, and B. Spiegelman. 1994. mPPAR 2 : tissue-specific regulator of an adipocyte enhancer. Genes \& Dev. 8: 1224-1234.

10. Tontonoz, P., R. Graves, A. Budavari, H. Erdjument-Bromage, M. Lui, E. Hu, P. Temps, and B. Spiegelman. 1994. Adipocyte-specific transcription factor ARF 6 is a heterodimeric complex of two nuclear hormone receptors, PPAR $\gamma$ and RXR $\alpha$. Nucleic Acids Res. 22:5628-5634.

11. Tontonoz, P., E. Hu, and B.M. Spiegelman. 1994. Stimulation of adipogenesis in fibroblasts by PPAR $\gamma 2$, a lipid activated transcription factor. Cell. 79: 1147-1156.

12. Gearing, K., A. Crickmore, and J. Gustafsson. 1994. Structure of the mouse peroxisome proliferator activated a gene. Biochem. Biophys. Res. Commun. 99:255-263.

13. Schmidt, A., N. Endo, S. Rutledge, R. Vogel, D. Shinar, and G. Rodan. 1992. Identification of a new member of the steroid hormone receptor superfamily that is activated by a peroxisome proliferator and fatty acid. Mol. Endocrinol. 6:1634-1641.

14. Zhu, Y., K. Alvares, Q. Huang, M. Sambasiva Rao, and J. Reddy. 1993. Cloning of a new member of the peroxisome proliferator-activated receptor gene family from mouse liver. J. Biol. Chem. 268:26817-26820.

15. Hu, E., P. Tontonoz, and B.M. Spiegelman. 1995. Transdifferentiation of myoblasts by the adipogenic transcription factors PPAR $\gamma$ and $\mathrm{C} / \mathrm{EBP} \alpha$. Proc. Natl. Acad. Sci. USA. 92:9856-9860.

16. Zhu, Y., C. Qi, J.R. Korenberg, X.N. Chen, D. Noya, M. Sambasiva Rao, and J.K. Reddy. 1995. Structural organization of mouse peroxisome proliferator-activated receptor $\gamma(\mathrm{m} \operatorname{PPAR} \gamma)$ gene: alternative promoter use and different splicing yield two m PPAR $\gamma$ isoforms. Proc. Natl. Acad. Sci. USA. 92: 7921-7925.

17. Chawla, A., E. Schwarz, D. Dimaculangan, and M. Lazar. 1994. Peroxisome proliferator activated receptor (PPAR) $\gamma$ : adipose predominant expression and induction early in adipocyte dfferentiation. Endocrinology. 135:798800 .

18. Le Marchand-Brustel, Y., B. Jeanrenaud, and P. Freychet. 1978. Insulin binding and effects in isolated soleus muscle of lean and obese mice. Am. J. Physiol. 234:E348-E358.

19. Lowell, B.B., V.S. Susulic, A. Hamann, J. Lawitts, J. Himms-Hagen, B.B. Boyer, L.P. Kozak, and J.S. Flier. 1993. Development of obesity in transgenic mice after genetic ablation of brown adipose tissue. Nature (Lond.). 366: $740-742$.

20. Hamann, A., R.C. Frederich, J.S. Flier, and B. Lowell. 1995. Synergistic effect of brown fat deficiency and western diet on the development of obesity, insulin resistance and hyperlipemia. Endocrinology. 137:21-29.

21. Lowell, B.B., and J.S. Flier. 1990. Differentiation dependent biphasic regulation of adipsin gene expression by insulin and insulin-like growth factor-1 in 3T3-F442A adipocytes. Endocrinology. 127:2898-2906.

22. Chomczynski, P., and N. Sacchi. 1987. Single-step method of RNA isolation by acid guanidinium thiocyanate-phenol-chloroform extraction. Anal. Biochem. 162:156-159.

23. Jakubowki, M. 1995. Receptor mRNA measurements by multiplex nuclease protection assay. In Methods in Neurosciences. Academic Press, Inc., San Diego, CA. 470-491.

24. Frederich, R.C., B. Löllmann, A. Hamann, A. Napolitano-Rosen, B.B. Kahn, B.B. Lowell, and J.S. Flier. 1995. Expression of ob mRNA and its encoded protein in rodents: impact of nutrition and obesity. J. Clin. Invest. 96: 1658-1663.

25. Zhang, Y., R. Proenca, M. Maffei, M. Barone, L. Leopold, and J.M. Friedman. 1994. Positional cloning of the mouse obese gene and its human ho- 
mologue. Nature (Lond.). 372:425-432.

26. Jakubowski, M., and J.L. Roberts. 1992. Multiplex solution hybridization-ribonuclease protection assay for quantitation of different ribonucleic acid transcripts from snap-frozen neuroendocrine tissues of individual animals. $J$. Neuroendocrinol. 4:79-89.

27. Issemann, I., R. Prince, J. Tugwood, and S. Green. 1993. The peroxisome proliferator activated receptor: retinoid X receptor heterodimer is activated by fatty acid and fibrate hypolipidaemic drugs. J. Mol. Endocrinol. 11:3747.

28. Gearing, K., M. Gottlicher, E. Widmark, C. Banner, P. Tollet, M. Stromstedt, J. Rafter, R. Berge, and J. Gustafsson. 1994. Fatty acid activation of the peroxisome proliferator activated receptor, a member of the nuclear receptor gene superfamily. J. Nutr. 124:1284-1288.

29. Issemann, I., and S. Green. 1990. Activation of a member of the steroid hormone receptor superfamily by peroxisome proliferators. Nature (Lond.). 347:645-649.

30. Dreyer, C., G. Krey, H. Keller, F. Givel, G. Helftenbein, and W. Wahli. 1992. Control of the peroxisomal B oxidation pathway by a novel family of nuclear hormone receptor. Cell. 68:879-887.

31. Yu, K., W. Bayona, C.B. Kallen, H.H. Harding, C.P. Ravera, G. McMahon, M. Brown, and M.A. Lazar. 1995. Differential activation of peroxisome proliferator-activated receptors by eicosanoids. J. Biol. Chem. 270:23975-23983.

32. Amri, E., F. Bonino, G. Ailhaud, N. Abumrad, and P. Grimaldi. 1995. Cloning of a protein that mediates transcriptional effects of fatty acids in preadipocytes. J. Biol. Chem. 270:2367-2371.

33. Brun, R.P., P. Tontonoz, B.M. Forman, R. Ellis, J. Chen, R.M. Evans, and B.M. Spiegelman. Differential activation of adipogenesis by multiple PPAR isoforms. Genes \& Dev. In press.

34. Tominaga, M., M. Igarashi, M. Daimon, H. Eguchi, and M. Matsumoto. 1993. Thiazolidinediones improve hepatic insulin resistance in streptozotocininduced diabetic rats. Endocr. J. 40:343-349.

35. Weinstein, S.P., A. Holand, E. O'Boyle, and R.S. Haber. 1993. Effects of thiazolidinediones on glucocorticoid-induced insulin resistance and GLUT-4 glu- cose transporter expression in rat skeletal muscle. Metab. Clin. Exp. 42:1365-1369.

36. Lehmann, J.M., L.B. Moore, T.A. Smith-Oliver, W.O. Wilkinson, T.M. Willson, and S.A. Kliewer. 1995. An antidiabetic thiazolidinedione is a high affinity ligand for peroxisome proliferator activated receptor gamma. J. Biol. Chem. 270:12953-12956.

37. Ailhaud, G., P. Grimaldi, and R. Negrel. 1992. Cellular and molecular aspects of adipose tissue development. Annu. Rev. Nutr. 12:207-233.

38. Tontonoz, P., E. Hu, J. Devine, E. Beale, and B. Spiegelman. 1995.

PPAR $\gamma 2$ regulates adipose expression of the phospoenolpyruvate carboxykinase gene. Mol. Cell. Biol. 15:351-357.

39. Steineger, H., H. Sorensen, J. Tugwood, S. Skrede, O. Spydevold, and K. Gautvik. 1994. Dexamethasone and insulin demonstrate marked and opposite regulation of the steady state mRNA level of the peroxisomal proliferator activated receptor (PPAR) in hepatic cells. Hormonal modulation of fatty acid induced transcription. Eur. J. Biochem. 25:967-974.

40. Rodriguez, J., G. Gil-Gomez, F. Hegardt, and D. Haro. 1994. Peroxisome proliferator activated receptor mediates induction of the mitochondrial 3 hydroxy methylglutaryl-CoA synthase gene by fatty acids. J. Biol. Chem. 269: 18767-18772.

41. MacDougald, O.A., C.S. Hwang, H. Fan, and M.D. Lane. 1995. Regulated expression of the obese gene product (leptin) in white adipose tissue and 3T3-L1 adipocytes. Proc. Natl. Acad. Sci. USA. 92:9034-9037.

42. Saladin, R., P. De Vos, M. Guerre-Milio, A. Leturque, J. Girard, B. Staels, and J. Auwerx 1995. Transient increase in obese gene expression after food intake or insulin administration. Nature (Lond.). 377:527-529.

43. Gulic, T., S. Cresci, T. Caira, D. Moore, and D. Kelly. 1994. The peroxisome proliferator-activated receptor regulates mitochondrial fatty acid oxidative enzyme gene expression. Proc. Natl. Acad. Sci. USA. 91:11012-11016.

44. Spiegelman, B.M., and G.S. Hotamisligil. 1993. Through thick and thin: wasting, obesity, and TNF $\alpha$. Cell. 73:625-627.

45. Lang, C.H., C. Dobrescu, and G.J. Bagby. 1992. Tumor necrosis factor impairs insulin action on peripheral glucose disposal and hepatic glucose output. Endocrinology. 130:43-52. 